Portland State University

PDXScholar

Summer 8-21-2015

\title{
Expressionist Art and Drama Before, During, and After the Weimar Republic
}

Shane Michael Kennedy

Portland State University

Follow this and additional works at: https://pdxscholar.library.pdx.edu/open_access_etds

Part of the European History Commons, German Literature Commons, and the Painting Commons Let us know how access to this document benefits you.

\section{Recommended Citation}

Kennedy, Shane Michael, "Expressionist Art and Drama Before, During, and After the Weimar Republic" (2015). Dissertations and Theses. Paper 2508.

https://doi.org/10.15760/etd.2505

This Thesis is brought to you for free and open access. It has been accepted for inclusion in Dissertations and Theses by an authorized administrator of PDXScholar. Please contact us if we can make this document more accessible: pdxscholar@pdx.edu. 
Expressionist Art and Drama Before, During, and After the Weimar Republic

by

Shane Michael Kennedy

A thesis submitted in partial fulfillment of the requirements for the degree of

Master of Arts

in

German

Thesis Committee:

Steven Fuller, Chair

Kathie Godfrey

Timm Menke

Portland State University

2015 


\begin{abstract}
Expressionism was the major literary and art form in Germany beginning in the early $20^{\text {th }}$ century. It flourished before and during the First World War and continued to be the dominant art for of the Early Weimar Republic. By 1924, Neue Sachlichkeit replaced Expressionism as the dominant art form in Germany. Many Expressionists claimed they were never truly apart of Expressionism. However, in the periodization and canonization many of these young artists are labeled as Expressionist.

This thesis examines the periodization and canonization of Expression in art, drama, and film and proves that Expressionism began much earlier than scholars believe and ended much later than 1924. This thesis examines the conflicts in Germany that led to Expressionism and which authors and artists influenced Expressionists. It will also show that after Expressionism ceased to be the dominant art form in Germany, many former Expressionists continued to use expressionistic form in their works but ceased to use expressionistic content. This thesis argues that both the periodization and canonization of Expressionism should be expanded to include all works that may be classified as having expressionistic form.
\end{abstract}


Table of Contents

Abstract.................................................

Introduction................................................

Chapter 1

History of the Movement....................................5

Chapter 2

Stylistic Aspects of the Movement.............................15

Chapter 3

Review of Scholarly Research..............................25

Chapter 4

A Closer Look.................................................36

Conclusions..............................................48

Works Cited..............................................52 


\section{Introduction}

Expressionism was a movement in the visual and literary arts that came to prominence in the early $20^{\text {th }}$ century. Its origins came predominantly from Germany, where it would be the most successful and influential. Expressionism shaped the aesthetic landscape and culture of Germany during the late $19^{\text {th }}$ and the early $20^{\text {th }}$ century. The early Weimar Republic became synonymous with the movement, but that is merely one aspect of Expressionism. The movement itself and its history remain surrounded in controversy. Historians disagree on when the movement started and when exactly it ended. John Willett argues that the movement began sometime around 1910 and only lasted until 1922. Other scholars argue that it lasted until 1924, and even more believe that Neue Sachlichkeit spelled the end for Expressionism as a whole. However, Expressionism's history spans a much longer time frame, both historically earlier and later than the dates critics give.

The history of Weimar and the First World War played a major role in the style and form of both the art and writings of the time. During the war, Europe saw dramatic changes in both the aesthetic landscape and artistic ideals norms on the content. Trenches were dug throughout Europe, and bombs and artillery shells formed craters. A combined total losses of close to 10 million, half of which came from the Central Powers, horrified Europe, and aided by new technological means of destruction-mustard gas scarred soldiers for life. Many of the authors and artists of the time had to fight in the war, or they saw first-hand the destruction the war brought to the continent. War forced a new 
generation of artist and authors to mature quickly due to horrific scenes and experiences. This was the fertile and toxic landscape out of which Expressionism blossomed.

Yet, Expressionism can trace its roots to earlier sources, especially the work Frühling Erwachen by Frank Wedekind in 1891 (Ryland, lxxxv). The onset of political paralysis in Germany in the early $20^{\text {th }}$ century pushed the movement impetus as a whole. While the onset of the First World War allowed Expressionism to step into the limelight of culture and take center stage. After the war, Expressionism forever became linked to the early Weimar years, especially because of Expressionist films. During the middle and late Weimar period opinions changed, Expressionism was cursed as a movement, and many of the artists who founded and worked in Expressionism swore off the moniker. However, expressionist style still continued to play a role in their artistic production, be it from Hanns Johst and Schlageter, written in 1933 during the early Nazi years to Der kaukasische Kreidekreis by Bertolt Brecht, which was written in 1944, near the end of the Second World War. Both works encompass aspects of Expressionism and show how artists still utilized the style.

Expressionism can also trace its roots in Naturalism, a movement that began around 1880. Naturalism sought to explore and show life for what it was. It explored society and social norms using detailed realism to prove social and environmental conditions shaped human character. Taking impetus from the writings of Charles Darwin and turned its implications into art. Naturalism portrayed the real world, but did not hesitate to criticize the status quo. Expressionism took this concept and added a psychological aspect. Expressionist artists and writers looked deeper than the visual world and explored how their views shaped what eventually the Expressionist perceived 
(Kuiper, 147). The early on Naturalist aspect was still present in much of Expressionism. However, Expressionists explored looking at how the mind viewed the world around it and not, like Naturalism, just using the eyes to perceive the world. The norms of Naturalism helped establish the defined norms of Expressionism (Best, Theorie des Expressionismus, 15).

The norms of Expressionism vary from the visual arts to literature. For the visual arts, Expressionism took the natural form of an object and distortted it to convey inner feelings and primal emotions. Bold and sharp colors added to place emphasis on the unmediated experience. Especially for drama, Expressionist wrote about what and how their characters perceived the world around them in both rational and irrational manners. In film and theater, Expressionist of the early Weimar period used sharp drastic sets to convey more emotion and representation of life was given more symbolism.

This paper will look critically both theater and film of the Weimar years to establish a basis for what Expressionism was at its peak. It will also use the visual arts of Expressionism to explain both form and content later seen in expressionistic drama. Expressionistic works can be traced from 1891 to 1945 . The goal of this thesis is to prove that the movement began much earlier than 1912 as the majority of critics argue, and ended much later than 1924.

Chapter 1: History of the Movement will look at the history leading up to, during, and post Weimar years to establish what fueled artists and writers of the time. It further examines the widespread disillusion with losing the war, the political upheaval, and the emphasis on rebellion. Also discussed are the artistic schools of Die Brücke and Der 
Blaue Reiter as emblematic modes of Expressionism. Lastly, this chapter ends with exploring Expressionism in cinema and literature.

Chapter 2: Stylistic Aspects of the Movement will analyze in detail the works that came before, during, and after the Weimar Republic. It will dissect the works in order to show what ideas and motifs, in both form and content, were Expressionist. It will particularly explore, themes of death, suicide, sexuality, and subversion of cultural norms.

Chapter 3: Review of Scholarly Research looks to explain Expressionism further using both critical scholars of the time and contemporary literary critics and explore what they believed about the movement. This chapter establishes the common theories on the movement, particularly the chronology for the development and evolution of Expressionism. Finally, the chapter analyzes the moniker "Expressionism" to assess the motive behind popular expressionists' denouncement of the name.

In chapter 4, Expressionism: A Closer Look, establishes my thoughts on how scholars focused more on content than in creating their theories of the Expressionist movement. Further research of the movement needs to be done in order to place literature that has expressionistic form into the canon of Expressionism. I will do a critical analysis of representative texts to show that Expressionism did indeed begin before and last longer than most critics argue.

Finally, my Conclusions section will show that Expressionism survived and was still used by artists and writers later than 1924, as the canonization and periodization of literature suggest. Even though the content of Expressionism faded, writers and artists continued to use expressionistic styles during and after the Second World War. 


\section{Chapter 1: History of the Movement}

Expressionism was a movement that began in the late $19^{\text {th }}$ and early $20^{\text {th }}$ century. The German Expressionist school traces its roots to the works of Vincent van Gogh, Edvard Munch, and James Ensor. However, the movement took root in Germany and quickly moved to the other European art capitals_-Paris, Vienna, Amsterdam, replacing Naturalism and Impressionism. The movement gained popularity during and after the First World War. The war fueled the inner ideas of Expressionism and those ideas continued to push the movement into the Weimar Republic and beyond.

Expressionism came to Europe at a time of distress and distrust throughout the continent. The Kaiser alienated many German artists in 1908 while doing an interview with the Daily Telegraph. The Kaiser talked poorly of the other nations in Europe and attested that Germans did not care about the lives or wellbeing of individuals in different countries. The movement started before the First World War, but many of the authors and artists used the war to fuel their creative work, most virulently the Dadaist (Benjamin, 22). The death and destruction seen throughout Europe led many young Europeans to question their leaders and the older generation. Furthermore, extenuating factors additionally lead to disenchantment in Europe. The lack of political and economic stability also drove the desire for socio-political change. By 1916, a semi military dictatorship took hold in Germany with the Kaiser in charge. The people wanted to elect their own leaders and were tired of the monarchist system. They also saw their all-butabsolutist leaders as father figures and fought to rebel against the older generation. The 
young were tired of the old guard making decisions that negatively affected their health and the health of the country. When the war eventually came, the environment was ripe for a new system to take hold, and Expressionism became that artistic form best suited to reflect that new urge toward individual and social rebellion.

Yet, Expressionism in Germany began well before the war. The two most notable groups at the start of the movement in the visual arts were Die Brücke, formed in 1905 in Dresden, and Der Blaue Reiter, which formed in Munich in 1911 (Gay, 13). Both these groups defined the Expressionist movement in both form and content, and their styles swept over Europe, especially in Berlin, during the war and the early Weimar Republic. Later in the Weimar Republic when Expressionism lost hold of as the dominant art form, the form of Expressionism continued to thrive. Expressionism worked with the horrors of modernity and Expressionists desired change in society. Expressionists wanted to see an Erneuerung des Menschen, a new form of liberty and liberation for the individual and by implication for society as a whole (Weisstein, 263). The way Expressionist painters accomplished this feeling and expressed their desire for change by using bright hues and large patches of color to express their inner feelings, moving away from an objective style of painting (Weisstein, 264).

Four Jugendstil architecture students founded Die Brücke in Dresden in 1905. Fritz Bleyl (1880-1966), Ernst Ludwig Kirchner (1880-1938), Erich Heckel (18831970), and Karl Schmidt-Rottluff (1884-1976) all played a major role in shaping expressionistic form and content. Taking its name from Nietzsche's Also sprach Zaratustra, these painters revolted against what they saw as the superficiality of Naturalism and Impressionism. They looked to reinvigorate German art with a spiritual 
side they felt it lost, and they did this through an elemental, primitive, highly personal and spontaneous expression. (Kuiper, 246)

Fritz Bleyl left the group early in 1907. Bleyl's main medium was woodcut prints. Bleyl designed the poster for the groups first art show, but it was not displayed because the police deemed the nude woman on it too provocative. Ernst Ludwig Kirchner, whose vibrant colors took hold in works such as Hamburg-Tänzer (1906), Nackte (1908), and Nollendorfplatz (1912) paved the path for film to follow. Their new style of painting rejected the objective and turned to the psychological and objective and replaced them with human expreience.

Similarly, Der Blaue Reiter was a group of artists united in rebelling against and rejecting the Neue Künstlervereinigung München. The group was founded by Wassily Kandinsky (1866-1944), Alexej von Jawlensky, Marianne von Werefkin (all from Russia) Franz Marc (1880-1916), August Macke, and Gabriele Münter came from Germany. They believed the principles of the Neue Künstlervereinigung München, a group Kandinsky helped to found in 1909, were too strict and traditional. Der Blaue Reiter instead wanted to express spiritual ideas through their works. They saw a connection between music and art and sought to express this by using vibrant colors and associating psychological meaning with the colors.

Wassily Kandinsky immigrated to Germany in 1896. His painting Der Blaue Reiter was the inspiration for the group. Kandinsky's paintings were large and vibrant with color. His works allowed for the colors to blend rather than meet at sharp dark edges. His works do not express the perceived world, instead his works focus on the feelings that the soul had on the world. Kandinsky saw his art as music. The works were 
spontaneous and done as improvisations, especially his work Über das Geistige in der Kunst from 1911.

Franz Marc's paintings of idyllic landscapes and colorful animals projected a romantic longing for change. Marc too wanted to distance himself from the conservative Neue Künstlervereinigung and paint what he felt. Although authors were not directly members of these groups, they were present as well. Expressionists consciously tried to blur the division of art into Kunstgattungen, mixing poetry, prose, music, and painting.

During and directly after the war, Expressionism in cinema promptly followed the artistic and literary movements as the technology of film became widely disseminated (Thompson, 111). Cinema was new during the time, and the cinema of Germany rivaled and surpassed its international counterparts. Expressionism was the driving device in many of the films, and their directors used Expressionist style to bring contrast and fear into their works. The Cabinet of Dr. Caligari, directed by Robert Wiene and released in 1920, heavily influenced Expressionists of the time, and further influenced modern-day horror films. F.W. Murnau's Nosferatu also used the chiaroscuro employed in Expressionism to instill fear into his audience. Fritz Lang's (1890-1976) 1927 film Metropolis became the best-known movie of its time. Its Expressionist symbols, flashbacks, and sets haunted Fritz Lang's film, allowing viewers to experience their inner fear. Finally, in F. W. Murnau's Der letzte Mann, normally considered a paradigmatic film of Neue Sachlichkeit, Expressionist form still haunted the screen, blurring the distinction between a social reality and the horror of the mind itself (Willett, 160) . New technologies like the ability to move the camera added in depicting this purely subjective and psychological aspect. 
Expressionist movements also existed outside of Germany, but Germany quickly became the focal point of their work (Kuiper, 140). The major dramatic authors of the movement were themselves German: Alfred Döblin (1857-1957), Frank Wedekind (1864-1918), Georg Kaiser (1878-1945), Gottfried Benn (1886-1956), and the young Bertolt Brecht (1898-1956). Many other authors, even after the heyday of Expressionism from 1912 to 1924 kept its major aesthetic values.

One the stage, Frank Wedekind's work Frühlings Erwachen was the first example of German Expressionist elements in theater. Written in 1891, the plays brutal portrayals of the status quo influenced many Expressionists to come. Georg Kaiser's play Von morgens bis mitternachts written in 1912, which later was adapted into a film, exhibited Expressionism through his portrayal of characters and their environments.

The poetry of Gorrfried Benn, a vehement critic of the Weimar Republic, voiced his opinion for change to a more nationalistic government. But early in his career his poetry focused on blood, death, disease, and how these things affected him. Finally, Brecht's most emblematic Expressionist work Baal, explored expressionistic themes of open sexuality, substance abuse, and death. These two generations of artists shaped Expressionism and its form and content, and influenced younger artist who continued to use aspects of the style. Alfred Döblin's novels show the rawness of the movement and the times through Franz Bieberkopf's drunkenness and the epic nature of the plot. After 1925, many of the younger generation of authors claimed not to be Expressionist and felt that although their work followed many of the key ideas of Expressionism, this did not make them Expressionists. As Kathleen Kuiper notes, 
The decline of Expressionism was hastened by the vagueness of its longing for a better world, by its use of highly poetic language, and in general the intensely personal and inaccessible nature of its mode of presentation. The partial reestablishment of stability in Germany after 1924 and the growth of more overtly political styles of social realism hastened the movement's decline in the late 1920s. Expressionism was definitively killed by the advent of the Nazis to power in 1933. They branded the work of almost all Expressionists as degenerate and forbade them to exhibit or publish and eventually even to work. (150-151) The subsequent art movements were indeed closely related to Expressionism, but they tended to change small aspects to better fit the shifting political views of the times. Even the many politically charged works of Neue Sachlichkeit relied heavily on the aesthetic developed by the Expressionists before them. The works by these writers put the groundwork for subsequent movements in place.

Perhaps the most influential author on the Expressionist movement was the philosopher, Friedrich Nietzsche (1844-1900). His works were initially instrumental in the writings of these Expressionists. Nietzsche's writing was the rage in the 1890's and in the first decade of the new century. By the time Expressionism became the en vogue art movement, artists drew heavily on Nietzsche's rejection of status quo within society and his desire for a new, critically passionate individual. Expressionists put Nietzsche's works on a pedestal, elevating them to the status of manifestos for the movement (Gay, 52). Nietzsche's nihilistic approach fit the resigned and frustrated mood during the early $20^{\text {th }}$ century. His proclivity toward questioning God and the power of human institutions of authority in turn allowed Expressionist artists to explore new styles. Nietzsche's 
writing became the staple for expressionistic thought. Young Expressionist artists took his philosophies and writings and molded them to express their inner distaste for the politics and authority of the time. Nietzsche's works became the catalyst for Expressionism as a movement. His writings were the starting point for many of these young artists and influenced a majority of their lifetimes works (Gay, 53).

However, Expressionist used the works of Nietzsche to a different end after the war was over. The stories of the Übermensch were no longer looked at as physical fights that one had to endure in order to achieve glory - it became an internal fight. Readers realized that to reach a higher level of humanity, consciousness, and self-actualization they would have to revoke their darkest of moments to understand the hidden innerworkings of the psyche. For many, this meant reliving the horrors of the war. Looking deep within themselves, the artists used Nietzsche's nihilism and combined it with the chaos of the early Weimar Republic. Expressionist used Nietzsche's writing to both cope and better understand the role the horror of war continued to play in their lives. Although written much earlier than the Expressionist movement, the publication of Nietzsche's writings could not have come at a more fortuitous time for German Expressionism (Ziolkowski, 213).

The aftermath of the First World War left the people and country in emotional, financial, and physical ruin. This turmoil allowed Expressionism and its aesthetic to influence and feed on the disillusionment of the public as a whole, but especially the artistic elite. After the war, many believed that the politicians and labor unions in Germany lost the war by refusing to support the continuation of the conflict. This led to distaste for the Kaiser and the old guard that had control of the country. Germany had 
united for the war, but the country divided just as quickly once the war ended. These young soldiers and intellectuals wanted a new form of government, one that they could create on their own and freely choose who was in office. This new government was the Weimar Republic. However, soon the younger generation of Expressionists too became disillusioned with the moderation of the new government. Another major factor to the inner angst and anger felt by Expressionist and Post-Expressionist authors was the Treaty of Versailles. Like Germans of all political backgrounds, some of the younger Expressionists felt the treaty was unfair and unjust. The treaty took Germany and pushed it into political and economic turmoil. It was insult added to injury for the people, that during the later years of the Republic lead to the economic chaos and hyperinflation that existed in the early years of Weimar. The Germans had lost their honor, land, and sense of power they had in the years before and during the war. These conditions served to radicalize the Expressionist movement toward social change that had earlier been centered on the role of the individual (Best, Theorie des Expressionismus, 23).

Most of the Expressionist and Post-Expressionist artists knew that it was not the soldiers that lost the war but the leaders of the country (Gay, 32). They witnessed the revolts in 1919 against the current system and the Kaiser. In 1919, the Weimar Republic was formed to the elation of many artists. However, this would be a short-lived victory for the Expressionists. Just as quickly as they rallied for the new republic, they wanted to dissolve it and create something more effective in its place. The Republic caused massive change in the major metropolitan cities, but had virtually no effect on smaller towns and villages in the country. Cities such as Munich and Berlin boomed and became havens for artists early on, but soon became dirty places for the rich and powerful to experiment 
with drugs, sex, and all fetishes imaginable (this is illustrated most starkly by Georg Groß in his work Ecce Homo). The Weimar Republic was made with the dreams of smart, well-read, rich, and commanding individuals inspired by the idealism of Goethe and Schiller. It was meant to be a place in which individuals could engage in learning and knowledge. Instead, the real Republic ended up being the opposite of what its creators had intended. This juxtaposition of theory versus praxis fueled the Post-Expressionists of the time, and later made artists renounce their original politics and develop a new radical style such as Neue Sachlichkeit. By the min 1920s, artists felt the purely Expressionist style had become impotent to reflect growing poverty and the political chaos of the time. Becoming more didactic in character, they wanted people to learn from what had happened and not veil their issues in vices. Artists still used a reduced Expressionist aesthetic, one mixed with direct and indirect calls for political change.

Ironically, Expressionism became the emblematic art of the time, only to have the original creators renounce its name (Best, Theorie des Expressionismus, 45). In the periodized canon of German drama Expressionismus ended in 1924 and Neue Sachlichkeit became the new popular style of art (Gay, 114). Neue Sachlichkeit sought to give art a new attitude. The ideas and its supposedly new artistic style still included those of Expressionism. Many former Expressionists denounced their original style, calling it childish (Gay, 112). However, they did continue to use common motifs, such as using sharp angles of film sets and referring to characters by their appearance or job title, in their later works that can be classified as Expressionist. In architecture, Expressionist style that lasted well beyond 1924 with buildings like Chilehaus finished in Hamburg in 1924 and Technische Verwaltungsgebäude der Hoechst $A G$ in Frankfurt, also finished in 
the mid 1920s. Expressionist architecture dominated Berlin's streets up until the Nazis took power in 1933. Even after the Nazis took power, Expressionism continued to manifest itself in the literary and theater world. The 1933 play Schlageter by Hanns Johst (1890-1978), although the paradigmatic play of the Nazi period, ends with a clearly Expressionist firing squad. The play is an example of a National Socialist Realism play, but the ending is strictly expressionistic (Braun, 273). 
Expressionism radically changed the style of art and drama during the late $19^{\text {th }}$ and early $20^{\text {th }}$ centuries. The movement took the styles of Impressionism, PostImpressionism, and Naturalism, and added the disillusion and frustration felt by those who lived under the Kaiser before and after the First World War. Expressionism looked to contort the real aspects of life and put inner-feelings as its main characteristic of the work of paintings and the stage. The new medium of film later used these ideas to evoke feeling with the sets and character makeup. Expressionism sought to escape from capturing the real world as it was objectively perceived, and instead turned to using harsh tones and colors in art pieces to express the artist's inner emotions. As for drama, it arose out of the styles of Realism and Naturalism, and eliminated the ideal aspects of life and replaced them with psychological horror and frustration of the individual in society (Clarke, 29). Expressionist abandoned nature and focused their art of inner Angst. The artists did this as reactions to the modern world and alienation felt from society in an attempt to create one's own identity. (Midgley, 15.)

Kathleen Kuiper best describes Expressionist Theater by writing, In forging a drama of social protest, Expressionist writers aimed to convey their ideas through a new style. Their concern was with general truths rather than with particular situations; hence, they explored in their plays the predicaments of representative symbolic types rather than of fully developed individualized characters. Emphasis was laid not on the outer world, which is merely sketched in and barely defined in place or time, but on the internal, on an individual's mental 
state; hence, the imitation of life is replaced in Expressionist drama by the ecstatic evocation of states of mind. The leading character in an Expressionist play often pours out his or her woes in long monologues couched in a concentrated, elliptical, almost telegrammatic language that explores youth's spiritual malaise, its revolt against the older generation, and the various political or revolutionary remedies that present themselves. The leading character's inner development is explored through a series of loosely linked tableaux, or "stations," during which he revolts against traditional values and seeks a higher spiritual vision of life.

There are common motifs in many expressionistic works that set Expressionism apart from different movements of the time. Death and suicide play major roles in Frank Wedekind's Frühlings Erwachen, Georg Kaiser's Von morgens bis mitternachts, Bertolt Brecht's Baal, and even Hanns Johst's Schlageter. Death and suicide continued to play a major role in many of the writings and films during the Weimar years (e.g. Trommeln in der Nacht written by Brecht in 1920 and Nosferatu directed by Murnau in 1922). Many of the writers, artists, and filmmakers saw the destruction of the War and wished to illuminate the inner, psychological scars that the war had left on its victims. Not just the scars left by the war, but also by the political change during the early $20^{\text {th }}$ century fostered Expressionism. The pain felt after the war in tandem with an unstable economic and political situation, left many feeling depressed and disheartened. Death and suicide, reflected by Expressionists and Post-expressionists, seemed like much better options than living through the aftermath of the war (Best, Expressionismus und Dadaismus, 10). 
An example of death and suicide appears in the early work of Frühlings

Erwachen by Frank Wedekind in 1891. The character of Melchior feels he knows every aspect of life. He dislikes the idea of God, "Ich sage dir alles.- Ich habe es teils aus Büchern, teils aus Illustrationen, teils aus Beobachtungen in der Natur. Du wirst überrascht sein; ich wurde seinerzeit Atheist.”(7-8) and feels he knows better than his classmates and his teachers. Melchior is also more experienced than his peers sexually and has no use for anyone beside himself. His friend and classmate, Moritz, represents the other side of the argument. He is inexperienced in all aspects of life and less intelligent that his friend. Moritz must work hard to get passing grades, whereas Melchior gets good grades without putting forth effort. Both characters work together and are close friends. Melchior, however, looks at his friendship as more of a game. He feels that he is better than Moritz throughout the play. In the end, his willingness to move on even after Wendla's and Moritz's deaths shows that he feels that he is the master of his destiny.

Von morgens bis mitternachts written in 1912 by Kaiser and Baal written in 1918 by Brecht also use motifs of death and suicide. Both works also show discontent for the modern times. The Kassierer in Georg Kaiser's work feels discontent for both his life and society and he becomes disenchanted with the life he lives. The main character is both literally and figuratively a prisoner to society, working in a cage and having no way of changing his situation. Once he sees the opportunity to free his life, through an accidental erotic encounter (a woman's naked wrist) he takes it. He soon learns that what he thought was the prefect life was nothing more than a mirage.

Schwerste Frage, Frau. Ich bin von wehenden Bäumen niedergeklettert, um eine Antwort aufzusuchen. Hier sprach ich zuerst vor. Es war doch selbstverständlich. 
Es ist ja alles wunderschön - unstreitbare Vorzüge verkleinere ich nicht, aber vor letzten Prüfungen besteht es nicht. Hier liegt es nicht - damit ist de Weg angezeigt. Ich erhalte ein klares Nein.(35)

He soon realizes that inner happiness is what he wants. However, he finds he can only achieve the illusion temporarily through people's love of money. He comes to recognize that money drives all aspects of life, and no one in society is pure. Everyone has a price and he learns this the hard way. The only way he can be truly happy is to end his own life. He comes to accept that the only way he can live in society is to not be a part of it at all when he says "Menschenscharen dahinten. Gewimmel verronnen. Ausgebreitete Leere. Raum geschaffen. Raum. Raum!" (67) The Kassierer, like many of the Expressionist of the pre Weimar Republic, felt suicide a much better option than continue to live under the authoritarian Kaiser. The Kassierer encompasses the feeling of the Expressionist. No matter how much acclaim they received through their art and writings, the Kaiser always overshadowed the artists and the people of Germany. Suicide seemed like the only way to gain any notoriety in Germany.

Baal is also an excellent example of death and suicide. Initially, Baal shows no worries about life or death. His life has become a game for him. His actions show distain for the business of art that supports his bohemian way of life. He is constantly drinking and refuses to preform for the crowd without alcohol. The character of Baal reflects that of Melchior. He is not phased about the death of Johanna. After he sleeps with her and the sisters come to have sex with him they mention she drowned. All Baal can say is “Schwimmt sie noch..."(36) He feels that it was her own doing and not his. Like Melchior he also does not acknowledge the pregnancies he is responsible for. He feels no 
remorse for the actions of others. The character of Baal encompasses the feelings artists had during the early Weimar years. The artists noted that nothing had truly changed and that the political system varied only slightly from that of the Kaiser. The rich still had power leaving the ordinary citizen to struggle. Baal is ready to die by the end of the play. Germans returning after the First World War just survived vicious and deadly combat. They were forced to struggle more when returning to Germany. The soldiers had fought for the Kaiser and felt betrayed by him when returning home (Gay, 132). Baal's disrespect to authority and nonchalant attitude towards death is a reflection of soldiers feeling after returning home from war.

Besides death and suicide, most expressionistic works express a discontentment with the authoritarian structure of society. Politics and Expressionism shared an odd relationship. While some writers like Brecht later supported Communism, others like Hanns Johst and Emil Nolde were avid supporters of the Nazi party. Expressionism became a means for many artists to express their varied political tendencies. Literature, along with newspapers and film were the catalyst and primary means of gauging political beliefs. Literature became the means of displaying political beliefs. Many artists and writers were in a state of discontent before the First World War. After the war, artists looked to express their discontent through their works (Gay, 155).

Frühlings Erwachen has early hints of discontent towards politics in the scene where the teachers and adults are discussing Melchior's fate. The authorities do not give him a chance to defend himself and refuse to believe that he had nothing to do with the death of Moritz. Instead of taking the burden of the blame on themselves for their strict rules and policies, they push blame towards Melchior. He becomes a scapegoat for the 
authoritarian system the adults set up. The exchange between Melchior, Sonnenstich, and the other teachers in act three scene one, exemplifies this power dynamic. Frau Gabor is the only one who defends Melchior.

Man hatte einen Sündenbock nötig. Man durfte die überall laut werdenden Anschuldigungen nicht auf sich beruhen lassen. Und nun mein Kind das Unglück gehabt, den Zöpfen im richtigen Moment in den Schuß zu laufen, nun soll ich, die eigene Mutter, das Werk seiner Henker vollenden helfen. (41)

Frau Gabor states that it was the teachers fault and not Melchior's. Frau Gabor believes that the teachers have let their power go to their heads. The teachers no longer listen to reason, once they have decided on an arbitrary verdict that is the choice they defend. Even if that choice is made to quickly or without sufficient evidence. Melchior had no chance in defending himself against the authoritative power of the teachers. His trial was nothing more than a show trial to indulge the authoritarian egos that the teachers built up for themselves. Melchior knew there was no way around a guilty verdict. Even though the teachers had the power, they were still a joke in Melchior's and Frau Gabor's eyes. Germans knew the Kaiser had power in name, but it was the political elite and rich that controlled Germany. There was no room to move up in the system, as Melchior experiences, and thee is no room to defend ones actions. This sentiment of discontent festered itself before and during the First World War and came out during the early Weimar period.

By the time Von morgens bis mitternachts was written, discontent for the Kaiser had reached a boiling point. The Kassierer feels the money he stole holds more power than anything else in society. But no matter how much money he has, he is still over 
shadowed by the Kaiser and the national anthem, "Daß es mir für die Fütterung von krummen Buckeln zu teuer ist," (Kaiser, 47) and "Dieser eben noch lodernde Brand ausgetreten von einem Lackstiefel am Bein Seiner Hoheit. Sind Sie toll, mich für so verrückt zu halten, daß ich zehn Pfennig vor Hundeschnauzen werfe? Auch das wäre noch zu viel. Ein Fußtritt gegen den eingeklemmten Schweif, das ist die gebotene Stiftung!" (47) Both show the Kassierer's distaste for the Kaiser. The money he puts down on the bike race stirs the crowd into a frenzy. However, when the Kaiser comes in the crowd pays more attention to the Kaiser than the money put down by the Kassiere. Outraged the Kassierer demands his money back, takes the money back, and storms out of the room in a rage. This scene mirrors the authoritarian and anti-authoritarian aspects portrayed in Expressionism.

After the war, writers took more liberties in openly discussing their distaste for the political system (Jonge, 47). The character of Baal in Baal is a symbolic figure for attitudes toward the government. Most Expressionist blamed the leaders for the loss of the war and no longer believed in their ideals. The way Baal treats others around him mirrors how artists treated the German government after the war. They did not take it seriously, they mocked it, they did not care what happened to elected officials, and they lost faith in where their lives were going. Many artists, dramatists, and Germans in general felt this way after the war and lived their lives in a hectic manner. Similarly, Baal does everything in his power to oppose the rule of others. Ironically, he becomes the master for many of his friends and acquaintances. By the end of the play, Baal's friends and acquaintances view Baal in a similar way to how Baal viewed society at the beginning of the play. Many Expressionists had a distain for the political status quo in the 
early Weimar period, feeling that it was too similar to the political system of the Kaiser that haunted them in the early 1900s.

Discontent for the Kaiser and society also manifested itself in the rejection of the father figure. Fighting against the father figure that represented all authority, likewise plays a major role in almost every work of Expressionism. Carl Zuckmayer noted that this, "was demanded of every good young writer" (324). The movement had always been a push to accept the modern and shifting aspects of life and the times, while destroying the past. The government, economic inequality, and indeed revolution became the focus of the younger generation. The liberal government shared little in common with this younger group. Examples of the rejection of the father figure follow the same guidelines as the rejection of society. Society was the symbolic father for these young artists and writers (Gay, 167). The fight between Melchior and the teachers, the Kassierer using money to overshadow the Kaiser, and Baal's constant rejections towards fitting in to the status quo of society are all examples of Expressionist fighting against their father figures.

Expressionism in film expressed these motifs in different ways. Filmmakers took the styles from Die Brücke and Der blaue Reiter and forged them into a style that shaped the film industry well into the 1930s. Film used sharp angles, shadows, and grandiose sets to convey the filmmaker's takes on Expressionism. These motifs shaped what many modern scholars now classify as Expressionism. Film cemented motifs and styles of Expressionism. Kristin Thompson explains why: "In 1916, the government had banned foreign films. The demand from theaters to generate films led to an increase in domestic film production from 24 films in 1914 to 130 films in 1918. With inflation also on the 
rise, Germans were attending films more freely because they knew that their money's value was constantly diminishing." (87) This coincidence allowed German filmmakers to take more liberties with their work and in turn explore different styles, Expressionism being the most prominent.

Many films such as Das Cabinet des Dr. Caligari, Nosferatu, and Metropolis are synonymous with Expressionism. Both Gay and de Jong write heavily on the two films. However, one film that many see as the first film of Neue Sachlichkeit, Der letzte Mann, continues to show examples of Expressionism (Jonge, 124). The release of the film in 1924 coincides with Neue Sachlichkeit, however, Expressionism is still present. Expressionist elements in the film include the identification with the uniform and not the self, the mobility of the camera, the dream/drunken sequence, and the scene showing the clock all convey expressionistic style through their ability to put the sharp angels and ideas from art into film. Modern film came from Expressionism in Germany in the early $20^{\text {th }}$ century and continued to use Expressionism well after 1924 (Kracauer, 243).

Not all writers and directors discussed in this thesis fought in the war (e.g. Georg Kaiser, Fritz Bleyl, or Bertolt Brecht), but all of them saw the struggles and turmoil of the individual in its aftermath. They were in a political system that did not coincide with their own beliefs. The new style expressed this shift especially in its portrayal of the hero. The brave soldier or rich monarch was no longer the focus of a story or the undisputed hero. Instead, the writers made them both villains and imperfect. The younger, less experienced characters were pushed to the forefront. These characters allowed the artists to show their own distaste for the politics of the older generation (Jonge, 56). 
The political and social conditions in Germany from 1910 to 1933 fostered a changing style of Expressionism. While its concentration became more political or indeed revolutionary, its earliest themes of aesthetic continued well after 1924 and the ascendency of Neue Sachlichkeit. The motifs of death and suicide, inner political angst, discontentment, and the fight against the father played major roles in forming expressionist aesthetic. These motifs influenced other art movements are key in determining if a work of drama or visual art is Expressionism or a different art form. 


\section{Chapter 3: Review of Scholarly Research}

As the previous chapters prove, it is difficult to define Expressionism in an exact time frame. It is an offshoot or a counter movement to Realism and Naturalism. In painting, it takes the light color palette and removed the emphasis on representing realist detail. Instead, Expressionism focuses on how one individual saw the world. At the same time, it removes the use of the real human form and forces the viewer to see the harsh colors and distorted psychology of its figures. Expressionism works less on developing characters as a whole; instead, Expressionists focused on making the characters a stereotype of the group he or she represented.

The genesis of Expressionism is difficult to ascertain. The term comes in to use well before the movement. One of the first theater works that includes the ideas of expressionist form is Frühlings Erwachen by Frank Wedekind written in 1891. This is

well before 1900, which is the year that many say began the movement (Wiese, 235). Harry Graf Kessler writes in his Tagebücher, "In German art, the transition from bourgeois to popular art had long preceded the Revolution" (91). Frühlings Erwachen comes well before the literary freedom that Weimar permitted. Peter Gay notes that Frühlings Erwachen is written, “... a year after William II had dismissed Bismarck, and long before the Emperor had fully tested his peculiar talent for disaster..." (3). Indeed this work is a starting point for the expressionistic style that swept across Germany for the next 30 years.

As a story about puberty and a loss of innocence, Frühlings Erwachen is indeed an excellent starting point. Wedekind's main character, Melchior, represents more than 
just an average teenager. Ideas from Nietzsche, that later played such a significant role in the expressionistic movement, are evident through his actions. He lives his life how he wishes to and focuses more on the "I will" aspect of life more than the "thou shalt". The character represents the new "Spring" that proliferated in the arts and literature of the time. Furthermore, the teachers add the most stylistic themes of Expressionism to the work. As Charlotte Ryland writes, the play “....approaches Expressionism in his treatment of the adult figures, and most particularly in the representation of the teachers" (lxxv). In no way or form are the teachers in the text realistic. Their names, for example:

Affenschmalz, Knüppeldick, Hungergurt, Knochenbruch, Zungenschlag, Fliegentod, and Sonnenstich. These names merely depict the attributes each character has and are perhaps given to them by the students to ridicule their personalities. Wedekind's characters are no longer individuals, but instead pushed into stereotypical roles. The teacher's names, unlike Melchior or Moritz who are individuals and have thoughts that are not preconceived, reflect exactly who they are in the societal petrified scheme of things. The teachers represent the harsh aspects of life and anyone who does not adhere to their autocratic style will be punished.

Another major aspect depicted in Wedekind's play that fueled the Expressionist movement is the fight that culminates at the end between the masked man (played by Wedekind himself in the first production) and Moritz. The push for Melchior to stay in the world of the living and embrace life is a spark for the movement. Despite the tragedy of the play, it has a heroic self-affirming end.

The visual art of the period, like the work of Wedekind, motivated the writers of the time and showed the world what Expressionism was. The critic Peter Gay looks 
deeper into this by noting, "Painters took the strong, simple, aggressive colors, the consciously primitive craftsmanship, the passionate line, and the cruel distortion of the human figure to new extremes" (106). Expressionist painters, he argues, stop looking at the outward world and become extremely individualistic and psychological in their style. Even artists who formed collaborative groups together, such as Der blaue Reiter and Die Brücke, consciously craft individual styles, although themes were similar.

By 1922, the title of Expressionist became one with which authors and artists did not wish to associate. As other movements like Cubism, Futurism, and Surrealism gain prominence in the early $20^{\text {th }}$ century, Expressionism is originally taken from the forefront and obscured. As Willett argues, authors like Brecht and Kaiser who are known for their expressionistic style forsake the label Expressionism and claim their works no longer have or ever had a resemblance to the expressionistic style. After 1922, some of the first Expressionist artists began to leave behind their purely Expressionist style and claim that the label never accurately represented them. An example of this is the work of Max Beckmann. By 1922, Beckmann eschewed Expressionism and claimed that his work never had anything to do with the style. He later said to the publisher Reinhard Piper that the "Expressionist business" was nothing more than "decorative and literary matter" (Willett, 120). Beckmann argues, "One can be new without engaging in Expressionism" (120). Many other artists soon followed the trend started by Beckmann and renounce the aesthetic label. Critics believe that after 1924 Expressionism is considered too mainstream for the artist and writers of the time. However, other critics argue the form of Expressionism continues well beyond 1924, the traditional starting year of Neue Sachlichkeit, and continues into the Third Reich (Bletter, 117). 
A few critics argue that, even though artists reject Expressionism, they continue to draw from it in both visual arts and drama. The most innovative and best-spoken Expressionists, especially during the Weimar years, are the playwrights. As Gay puts it; "Prolific and hostile to the rules, to the audience, often to clarity, the poured out plays eccentric in plot, staging, speech, characters, acting, and direction. Sets were merely indicated; lighting left the spectator much to do; speech rose to declamation and, often, sheer yelling, as far removed from ordinary manner as possible. These plays had much life, little elegance, and absolutely no humor; their appeal was strident and utterly direct, a cry for help and an emphatic, impatient demand for reformation" (110).

Clearly, while artists reject Expressionism in name, they still draw from its stylistic menu.

Almost all scholars of Expressionism argue that the playwrights are a precursor and inspiration for what later came in Expressionist film. During both the early and late periods of the Weimar Republic, Leopold Jessner (1878-1945) helps shape Expressionist theater. The formation of the Jessnertreppe in late 1919 becomes an "assault on Naturalism, and an Expressionist demand that the audience participate in the drama by using its imagination" (111). As his style continues to progress, it introduces new heroes, or rather anti-heroes, such as a stranger, a prostitute, or a suicidal person. Using a Freudian metaphor, Gay calls this new form and introduction of these aspects "the son's revolt against the father" (113). Carl Zuckmayer mirrors this idea in his work Als Wär's ein Stück von mir by casually writing, "In that time, the father-son conflict was demanded of every good young writer" (324). Just like the artists that distance themselves from the 
movement, the playwrights follow suit. The 1925 election of Paul Ludwig Hans Anton von Hindenburg ushers in the rise of the father figure in Germany and a collapse of the son; yet, in this instance, Expressionism and the art forms still challenge the old way (Best, 69). Expressionist theater lays the building blocks that later influences the filmmakers. Theater and playwrights cement what Expressionism is seen as today. Although many writers work in the Expressionist style, after 1918 it is the new invention of film that disseminates Expressionism to the people in the early 1920s. "The German film industry in the 1920s," Jonge writes, "was one of the most advanced in Europe if not in the world" (147). The Expressionist style advances and cultivates itself in the works of Georg Kaiser, Bertolt Brecht, and Franz Kafka. Films allow for a much wider audience to see the style and its themes. Film takes the sophistication of the theater and enables the working class to enjoy what they previously did not have access to. During this time, it is easier to make a movie and show it to millions than write a play that might only be seen by a few thousand.

The first major film that launches Expressionism into the public eye is The Cabinet of Dr. Caligari, directed by Robert Wiene. The film not only encompasses the ideals of Weimar but the style of Expressionism. As Gay notes, the film “...mirrors the uncertainties and the confused thinking of the Expressionist" (105). Films, like literature, place characters into roles based off of stereotypes. The character is not the centerpiece of the work, but instead the story is. Yet, Expressionism catalyzes its own financial downfall in the film industry. With meticulous sets, moving cameras, and the use of lighting to create the desired effect, the money going into the industry is strained. After the Universum Film AG, UFA, makes the film Metropolis they go bankrupt. Alfred 
Hugenberg, a right wing media mogul, subsequently bought the bankrupt studio. He sympathized with the Nazi Party and Expressionist films were pushed out of the mainstream by 1924 (Thompson and Bordwell 102).

Expressionism utilizes the early ideas of Wedekind and forms them into a coherent art and literary style that plays a major role in the Weimar years. The discontent for authority continued throughout the Expressionism movement. Expressionism was a breath of fresh air for many younger people during the early years of the republic. Young people had seen the struggles of war first-hand. But as Gay points out, "Some mistook Expressionist declamation for a reform program..." (74). It is this idea, he argues, that angers many of the artist and writers who worked in this style. However, Expressionism was more than a singular look at politics. People from a variety of political backgrounds are considered expressionist. Gay reminds readers of this with a short political bibliography of Emil Nolde; “...his vicious anti-Semitism, his crude hostility to French culture, both underlined by his early membership in the Nazi Party" (107). “Expressionism was," as Gay puts it, "compatible with all sorts of politics” (107). For example, Bertolt Brecht, who devoutly sympathizes with the Communist cause, used Expressionism in many of his early works, and continued to use expressionist elements later in his career. Expressionism was meant to be an escape from what had been; it was an escape from the social injustices that many endured during the time. However, Gay comments that "...they were in general revolutionary without being political or, at least, without being programmatic..." (105). That escape never came. Many people felt betrayed by the lack of success of the movement and sought to forge new styles that better fit their social agenda (Willett, 144). 
Expressionism dominated the life of Weimar from 1918 to 1924. During a time of revolution, France's occupation of the Ruhrgebeit, political turmoil, and rising inflation, it is clear that Expressionism dominated with its harsh colors and psychological portrayals. (Gay, 21) However, around 1924 the harshness of life in Weimar was about to change. There was less political unrest, the economy had stabilized, and the citizens were enjoying a higher standard of living, with Berlin, an artistic capital of the world, fueling it. With this change came a new movement that dominated and pushed Expressionist ideas to the background. This novel form was Neue Sachlichkeit. This innovative movement looked to engage with and utilize objects that were present in the artist's or writer's world. Expressionism attempted to eradicate any order or objectivity in a piece. Neue Sachlichkeit, on the other hand, wanted the facts of the world and presented them as they were. There was no need for inner feelings or introspection in this movement.

However, Expressionism had been criticized even before the advent of Neue Sachlichkeit. "The Expressionist wanted a new culture," remarked Hojo Holborn, "but few others wanted a new culture, and those who did went over to Germanic Socialism" (45). Max Weber saw Expressionism as problematic in 1918 and demanded something new. Max Weber is quoted in the Ein Jahrhundert Frankfurter Zeitung as saying, "the only road to authenticity and education of conscience—Schamgefühl" (15). As time continued, more and more writers and artist were denying that they were or had been Expressionists. Carl Zuckmayer, whose early work was Expressionist, later said he found the style "...alien and that it expressed no breath of reality. The style", as he said, "was worn out.” (324) Bertolt Brecht, whose initial work also had expressionist ideals, helped popularize this new style of Neue Sachlichkeit (Kuiper, 150). Brecht believed that 
Expressionism was too superficial. Many artists found the cynicism of Expressionism to be overwhelming. Neue Sachlichkeit allowed the artist to express happiness for the objects around them. Gay best describes this by stating:

It was a movement toward simplicity and clarity in which many of the Expressionist could join, not merely because they were weary with old modes or venally adapted themselves to new fashions or experienced outright conversion; Expressionism itself had contained impulses toward objectivity, which now gained the upper hand. (122)

Critics argue, that by 1924 Expressionism had been replaced as the dominant art form of the time. Indeed Neue Sachlichkeit was welcomed by many of the Expressionists. Artists such as Brecht and Döblin spoke out against Expressionism. However, it is difficult to see the change that artists and dramatist made throughout the period ranging from Expressionism to Neue Sachlichkeit. In Art Journal, Rosemarie Haag Bletter argues that the transition was not as easy as some authors made it appear. She asserts, "Architects, and other artists for that matter, did not change hats as they passed from one period into the next. The close association of an artist with a specific movement makes sense only if he achieved his greatest importance during that period" (118). As Bletter writes, many artists are included in both categories. Neue Sachlichkeit takes the form from Expressionism, but leaves the content Expressionism discusses behind. Neue Sachlichket did not replace Expressionism, it is merely surpassed as the dominant art form. Expressionist did not leave the movement, the simply moved on to a new artistic movement while continuing to draw on what they learned from Expressionism. 
A number of critics seem to understand that Neue Sachlichkeit is not the end of Expressionism. "Today however," writes Willett, "when the moral superiority of figurative to non-figurative is no longer quite the article of faith it once was, we can see that several of the qualities sought by the Neue Sachlichkeit artists are also to be found in those outside the movement" (116-117). It is indeed difficult to distinguish the art and writings from one period to the other. Many of the same styles both movements utilize, the difference being how much the mind of the artists is present in the work. Shifting priorities on what was important is the only change it went through. Stylistically, very little changes after 1924. Even the artists who left Expressionism to explore a new style still kept major themes and motifs that are strictly Expressionist. Scholars attempt to give definition to the two movements. Ulrich Weisstein looks closer as to why it is difficult to see Expressionism in the movements that followed and why so many rejected it.

What makes it so difficult to give Expressionism its due is the fact that, at its very heart, it was beset by problems arising out of a series of dichotomies, and that, consequently, it was caught in the vise of a dialectic from which it could not properly extricate itself. Inevitably-or so it seems-the Expressionist work of art is suspended between two poles, the realistic and the idealistic. (271-272)

Neue Sachlichkeit is always an extension of Expressionism; all art movements draw on one another in some aspect. The same can be said when a new movement takes over. The old movement is still relevant, just not as popular. As many artists and writers made the transition to the new, dominate style, they continued to use the expressionistic style they originally used. Be it consciously or unconsciously, these artists allow common themes of Expressionism seep into their newer works. The relationship between the authors, artists, 
and Expressionism became a symbiotic relationship. As the new forms flourished, the old form, Expressionism, is still present. It gives to new forms but affected content to a lesser degree (Bletter, 113).

The true end of Expressionism cannot be generalized to a specific year. Critics argue the dates that it is said to have ended range from 1922, two years before Neue Sachlichkeit took hold of the art world, to 1933, the rise of Nazi Germany and the Third Reich. Expressionism found little support in the Nazi period. As Braun notes, Josef Goebbels looked at the movement "as the programmatic deformation of reality"(274). The Nazis had no need for this form of art, but that does not mean they did not indulge in it. "During the early years of the National Socialist Party," writes Emily Braun, "Expressionism was even supported by some members as true to the mystical German spirit, and the heir to the national indigenous Gothic style" (273). Expressionism, even though considered Entartete Kunst, was still being produced. "Under Nazi rule," explains Jay A. Clarke, "most of the German Expressionists were derided and branded "degenerate" artists; they were forced to flee Germany or discontinue making art altogether" (25). It did not help that these artists and writers were anti-Hitler and many Jewish. Even still, the right-wing Expressionists like Hanns Johst continued to thrive in Nazi Germany. Expressionist form stayed with Johst and influence his plays like Schlageter.

Expressionism is difficult to put into a historical context. Its origins, just like its endings, are unclear. Most scholars agree that Nietzsche had a major influence on the movement. Another accepted idea is that Frühlings Erwachen, released in 1891, was the first work written that had expressionistic form and tendencies. As time progressed the 
movement became less and less en vogue. However, the movement survived longer than some scholars believe and did not fade away with the advent of Neue Sachlichkeit. Expressionism did not end in the early to mid-20s. Instead it continued to play a role in the works of the late 20s and early Nazi period. 


\section{Chapter 4: Expressionism: A Closer Look}

Some scholars, such as John Willett, believe that Expressionism only lasted until 1922, while others claim that it ended in 1924. Willett even goes as far to assert that the movement only had a 12-year history, starting only in 1912. With Neue Sachlichkeit taking form in 1924, it is easy to surmise why many saw this as the end of Expressionism. It seems as though Willett's estimation of the period's longevity is flawed. Willett prematurely assigns dates to the movement and Expressionism certainly began much earlier than 1910 and extended past 1922.

In terms canonization regards to periodization, scholars cannot give a definitive beginning and ending to any literary or artistic movement. Ideas and styles begin to emerge well before a movement is named, noticed, or labeled. Writers such as Friedrich Nietzsche, Sigmund Freud, and Frank Wedekind planted the ideas of Expressionism in works such as Frühlings Erwachen late in the 19th century. Nietzsche's writings and philosophy were major influences to the Expressionists of the time. Freud's work, starting around 1900, looked into the human mind to discover inner truths about humans and what motivates individuals established itself as a common motif. Expressionist authors also drew from Freud's writings on sexuality and repression of both heterosexual and homosexual urges (Weisstein, 270).

Wedekind, however, wrote in an expressionistic style that helped lay the groundwork for authors who followed him. Frühlings Erwachen was written in 1891, nineteen years before Willett stated that the movement began. Although the play was not traditionally written with the intent of being an expressionistic work, it offers many 
stylistic examples and motifs found in Expressionism. The play starts in Naturalism and ends in Expressionism. For example, Melchior proclaims that he is an atheist and does not believe in God is directly expressionist. He openly talks about sex and the fact that he has more experience with the topic than his classmates also indicates that this is a work deeply rooted in Expressionism. Moritz, on the other hand, and his struggle to compete with Melchior, Wendla's search for knowledge about where children come from and her mother's unwillingness to tell her daughter, the homosexual relationship between Hänschen and Ernst, and the search for sexual openness by the students, i.e. them masturbating at the reformatory, are all overtly expressionistic topics as well. These scenes echo the aesthetic and social program of Expressionism by putting emphasis on the characters as opposed to the world around them. The characters focus on their own suffering and problems, which in turn creates an insular world within the play. The descriptions of the scenes are immaterial, whereas the characters become momentous and symbolic of the time. The aspects of Wedekind's play that were most influential on Expressionism were his portrayal of the teachers and the enigmatic character of the masked man (Ryland, lxxv). Wedekind, without knowing, gave young writers a rough blueprint for expressionistic writing. His work is the starting point in the move from Naturalism to Expressionism.

Introducing the element of the ghost and the supernatural would later be a standard in expressionistic films. Films such as Das Cabinet des Dr. Caligari, Nosferatu:, eine Symphonie des Grauens, and Metropolis continued to incorporate aspects of the supernatural. The conflict scene at the end of Frühlings Erwachen is supernatural and 
expressionistic in that it exemplifies the dichotomy between life and death. The scene, as Charlotte Ryland writes,

...anticipates the Expressionist obsession with cataclysmic new beginnings. The Masked Man's beseeching of Melchior to embrace vitality and to look towards the future contains the kernel of the dynamism that was to furl the Expressionist movement. (lxxvi)

Wedekind's play was a precursor to the Expressionist movement. Yet, it was also part of the movement as a whole. Unlike Willett's assertion, the movement began well before 1910. Wedekind's play and his subsequent work are Expressionism. His play gave other Expressionist artists an evocative style to emulate. However, his work should be seen as more than a preceding element. It should be considered an integral part of the movement and it should be included in the canon of Expressionism.

Von morgens bis mitternachts was an early expressionistic play written by Georg Kaiser. Written in 1912, it drew many of its motifs from Nietzsche. The play also took the hate felt toward the status quo and projected that angst toward fueling the actions of Kassierer. Moreover, the main character did not take the time to get to know the woman that came from Italy. Instead he eschewed the outer world that surrounded him and only concerned himself with his inner feelings. He confronts the woman face to face and must cope with and further acknowledge his own reality. He chooses to reject his physical reality. After he accepts what had happened, he realizes he is now the master of his destiny. He no longer needs the approval of his job, his wife, or his family. He reaches self-actualization and discovers that he is now the only person that he had to please and to who he was accountable. This idea of Erneuerung des Menschen plays a major role in 
Expressionism. Expressionism aimed at the renewal of man and freed the literature from traditional aesthetics (Wiese, 307).

As the story continues, the main character pushes his own boundaries and the boundaries of those around him. He used the money, a false idol, to influence the reactions of others. "Ärgern Sie mich nicht,“"writes Kaiser, "nicht mit den Bengels. Das Publikum kocht in Erregungen. Das muß ausgenutzt warden. Der Brand soll eine nie erlebte Steigerung erfahren" (44). At the 7-day bicycle race, the main character bolsters the crowd with money and enjoys the visceral reaction of both the upper and lower class audience members. He forces the people to revert to their animalistic instincts rather than act like humans. In every instance, the bicycle race, the woman at the brothel, and the meeting at the Salvation Army hall, show that money has more influence over people than any human virtue. Even the Salvation Army Girl submits to the pitfalls of money and wealth. Nietzsche often wrote about how people should not succumb to false idols, most evident in his work Also sprach Zarathustra: Ein Buch für Alle und Keinen. Another theme of Nietzsche Kaiser utilizes in this work is that each citizen obeys and respects the Kassierer due to his wealth. Kaiser wants readers to know that following a false idol is not the road to happiness. One has to acknowledge and enjoy his or her own actions and consequently be accountable for those actions. The Kassierer realizes this lesson by the end of the play, but not without cost. Learning this lesson leads him to kill himself. He acknowledges his guilt and knew the only way to be accountable for what he did was suicide. The fact that he died in the form of a cross and his suicide are common motifs of expressionist works. Christ-like death redefined Christ and Christianity as a deformation rather than a solution (Wiese, 308). 
In many similar ways, Bertolt Brecht's post war play Baal indicates that his early writing were expressionistic. Many of the same motifs that are in Frühlings Erwachen are also present and mirrored in Baal. The main character, Baal, an undisciplined and despicable antihero, considers sex and sexual encounters as nothing more than an act containing no virtue or moral imperative. The work not only looks at heterosexual relationships, but also includes a homosexual affair between Baal and Ekart. The rampant alcoholism of the characters serves as a demonstration of the cataclysm and inner turmoil that Expressionists felt during the time. The character's drunkenness draws the emphasis away from the outer world and forces the reader to focus on the character's emotional state. As much as Brecht tries to get the reader to see reality that exists externally from the characters, their inner workings and dialogues always force the emphasis away from society. As most critics argue, Baal is a paradigmatic play of late Expressionism, both in form and content.

Peter Gay explains this style of expressionistic writing by stating, "Prolific and hostile to the rules, to the audience, often to clarity, the poured out plays eccentric in plot, staging, speech, characters, acting, and direction" (110). Baal warns the reader of continually changing feelings, keeping the audience alert of ever changing emotional states. The chaotic nature of the characters makes it difficult to judge them only at face value. The characters are neither good nor bad. Instead, they choose to live their lives in limbo. In the beginning, the characters attempt to earn the respect and admiration of Baal. Baal loves the power bestowed upon him by the others, but as the play progresses, the characters rely less on Baal. Baal eventually leaves the group when his peers realize he too is a false idol. As a last ditch effort to regain power, Baal murders Ekart. The struggle 
of attaining and subsequently losing power is a constant theme in expressionistic works. This style stems from the pervasive struggle faced after the Great War. Even though Brecht later renounces that he was an Expressionist, the style followed him throughout his career. "It was a movement," as Gay writes, "toward simplicity and clarity..." (122). Any writer who lived through the First World War continued to use expressionist styles as a means of coping with what was seen and experienced (Denkler, 3).

An example of right wing Expressionism is Schlageter by Hans Johst, written in 1933. This concept of right-wing Expressionism was not new to the movement. Emil Nolde for example was a prominent early supporter of the Nazi Party. Expressionism did not automatically make artists and authors of the time more or less liberal. Some authors supported the Weimar government, while others supported the old Kaiser, and some looked to the future and believed that the Nazi Party was the correct form of government to follow. Emily Braun notes that even during the beginning of the Nazi's rise to power, "Expressionism was even supported by some members as true to the mystical German spirit, and the heir to the national indigenous Gothic style" (273). These members praise the style of the time and continued to use it as the party took power. However, there were opponents to Expressionism in the Nazi party. Joseph Goebbels viewed Expressionism as a menace to society and a destruction of reality (Braun, 274). As time continued to the more formative years of the party, the mood toward expressionists changed for the worse. Jay A. Clarke makes this clear in his look at Expressionism in Germany; "Under Nazi rule most of the German Expressionists were derided and branded 'degenerate' artists; they were forced to flee Germany or discontinue making art altogether" (25). But just because the artists fled did not mean Expressionism left Germany with them. 
Johst, like many other authors of the time, was affected by Expressionism. The movement inspired his early works, for example Der Einsame, written in 1917. As he progressed as an author, his later style began to take political shape. As a patron of the Nazi movement, he wrote Schlageter in 1933. Slogans from the play became battle cries the Nazis took to heart. The best-known slogan from the work shows the mindset that the Nazis had throughout their entire reign; "Wenn ich Kultur höre, entsichere ich meinen Browning."(10). This quote echoes the ideals of the Nazis. The play did still had expressionistic tendencies that soon came to the front, reminiscent of Kaiser's work Von morgens bis mitternachts. This is most notable in the execution scene. Schlageter's final words before his execution echo the sentiment felt as the Nazis rose to power: “Deutschland!!! / Erwache! / Entflame! / Entbrenne! / Brenn ungeheuer!”(28) The main character is a Christ-like Nazi figure. The words and posture of Schlageter's body after death are reminiscent of the final scene in Von morgens bis mitternachts by Kaiser. The style in which this was written, however, reveals more about the author than might have previously been unknown. The passage is both propaganda and Expressionism. "The tradition of the Expressionist cry is obvious," notes Ingo Roland Stoehr, "but the passage also reveals how dramatic linguistic effects and a bloodthirsty rhetoric have to make up for content that is anemic because of its propagandistic one-sidedness" (181). The Nazis use Expressionism for its ability to convey a wide variety of emotions and use it to send extreme political messages. Although they denounced the art form as a whole, styles from the movement, both artistically and literary, continued to play major roles in the theater and visual arts throughout the era (Braun, 276). 
Another key example of Expressionism extending past the preconceived end year of 1924 is the work, Der kaukasische Kreidekreis, of Bertolt Brecht written in 1944 and preformed in 1945. The work itself is not Expressionism, but the form of Expressionism is still evident in parts of the play. Brecht later wrote in the style of Socialist Realism and start a new form of theater, Epic Theater. As with most art movements, it borrowed ideas from those that came before it. Brecht's Epic Theater was no exception. Some of his later works retained stylistic points in the form of Expressionism. Der kaukasische Kreidekreis focuses on the struggle of the individual trying to assimilate into mainstream society. The main character, Grusche, attempts to find a place to live for her and the baby Michael, but is continually pushed away. The story focuses on the inner struggle she faces and her emotional turmoil as she tries so hard to keep the baby Michael, the one thing that she truly cares about. As the play continues, Grusche learns that even though the world may be harsh it gets better. Grusche serves as the miserable loser. She has the opportunity for an easier journey by neglecting to pick up Michael, but her inner struggle with her own guilt forces her to pick up the baby boy. Every time she feels that she had made it to another, better place, she is drawn back to the harsh struggle she faced until the end of the play. Grusche exemplifies failure despite doing the right thing, a major motif in Expressionism.

Many of the characters in Der kaukasische Kreidekreis are called by their job title instead of their true name. Their real names are said; however, they are not used to denote them as a character, for example: der grösste Junge, der dicke Junge, der Gefreite, and der Sänger. Many of the characters are defined by their social status, similar to the teachers in Frühlings Erwachen. The name given to the characters is presumably all the 
information the audience needs. The Large and the Small man is all the reader needs to know about the characters. Likewise, the military members have lost their names and are now just known by their ranks.

Finally, the singer and his musicians do what their names say they do. The singer's name, Arkadi Tscheidse, is given to the reader, but every time the character is mentioned in the play it is always by the title of Sänger. Brecht uses this same style of writing in Baal. This form of Expressionism forces the reader to find themselves in the characters, adding to the audiences alienation from the play.

The pinnacle of Expressionism portrayed in Der kaukasische Kreidekreis are the songs and poems that der Sänger sings. His songs portray the darker aspects of the mind. The songs tell stories of the past in vivid detail. The songs mirror the early style that Expressionists used. The songs take what der Sänger perceived, but they add his feelings on the issues to the scenes. Der Sänger's words are reminiscent of those used by Brecht in his earlier work Baal. The songs convey the psychological and emotional aspects that are common in the early works of Expressionism. An excellent example of this comes when der Sänger sings about the changing in the seasons, "Die Schwester war zu krank/ Der feige Bruder mußte sie beherbergen/ Der Herbst ging, der Winter Kam/ Der Winter war lang/ Der Winter war kurz/ Die Leute durften nichts wissen/ Die Ratten durften nicht beißen/ Der Frühlingdurfte nicht kommen." (58) This poem works in the same harshness that the Expressionist uses during the early Weimar years. Even though the content of Brecht's later works are not specifically Expressionist, many of the forms he uses stayed in the form of Expressionism. 
Literature is not the only art form of the time that indicates Expressionism goes past the 1924 end date. Expression in film reaches its dawn in the early 1920s with films such as Das Cabinet des Dr. Caligari and Nosferatu, eine Symphonie des Grauens respectively released in 1920 and 1922. Both films focus on the feelings of the individuals and refuse to let the community take control. The viewer may know a little about the character, but never enough to know what the characters motivations are. The set design in both also encompass motifs of Expressionism. They are painted unrealistically, and the majority of the shadows do not need lighting effects. Instead, the shadows are painted onto the set in order to emphasize the contrast of black and white. None of the shadows are painted at right angles to further evoke emotion. The problems faced by the characters in these films imitate the sets. The world contrasts differently from them, and they must try to find a place and meaning in a world that does not represent who they are.

By 1924, Neue Sachlichkeit seemingly replaced Expressionism. Directors were now claiming their films were no longer expressionistic works, but instead were part of the new art movement. This can be best seen in a film directed by F.W. Murnau titled Der letzte Mann, made in 1924. This film is looked at by scholars as one of the first Neue Sachlichkeit films of the era (Willett, 127). The film implements a mobile camera for the first time, which allowed for a smoother story. However, Expressionism still played a role in the film. "Nonetheless," argues Willett, the scholar who believes Expressionism ends in 1922, "the commercial productions attributable to the Neue Sachlichkeit spirit were by no means all disastrous. Admittedly some of them, like the succession of 'street' films, retain more of the mannerisms of Expressionism than generally acknowledged" 
(146). Many of the actions Murnau uses in the film are expressionistic. The way the camera moved introduced a new way for directors to film the world. The dream sequence after the Hotelportier gets drunk is highly expressionistic in the lack of realism with him being able to move luggage with no effort. The distorting of the camera lens allows to audience to feel the same drunkenness the character does (Alfred Döblin later used dream and drunken scenes like this in the novel Berlin Alexanderplatz)(Willett, 130).

Finally, the most expressionistic films of the time is Fritz Lang's Metropolis. Made in 1927, it comes three years after most scholars claim the movement ended. The film utilizes strong and weak chiaroscuro to emphasize the emotion of scenes. The film uses other German expressionistic motifs; the two clocks representing social class and the amount of work needed to be done, the robotic like shift changes the workers go through, the forming of the machine and its supernatural like presence, the wild urban setting, and the madness that comes from being in this setting. The film continues to use motifs and themes that point more to Expressionism than Neue Sachlichkeit (Kracauer, 246).

Many scholars believe that Expressionism ended somewhere between 1922 and 1924. John Willett even goes as far to say that the movement only lasted from 1910 to 1922. However, this is not the case. Expressionism begins much earlier, in 1891, with Frühlings Erwachen and continues much later than 1924. Expressionism is still seen in 1945 in the work Der kaukasische Kreidekreis by Brecht. Expressionism shares many ideas with other art movements, but it still has its own individual aesthetic.

Expressionism cannot establish a time period with exact certainty. Looking at the evidence presented, Expressionism was a legitimate art form for longer than its 
traditional periodization in the canon. It was used over a 50-year period and indeed still influences works today. 


\section{Conclusions}

Expressionism was an artistic movement that cannot be defined to specific years. Like all art movements its beginnings and endings cannot be rigidly defined as many scholars do. Expressionism traces its roots from Naturalism and forged itself during the late $19^{\text {th }}$ early $20^{\text {th }}$ centuries. It replaced the previous styles of Realism, Naturalism, and Impressionism. It was a style that began in Germany but soon manifested in other European capitals such as Paris, Vienna, and Amsterdam. The movement gained popularity before and during the First World War. Groups such as Der blaue Reiter and Die Brücke laid the artistic groundwork of the movement that was later be used in film and theater. The First World War fueled the inner ideas of Expressionism that continued to push the movement into the Weimar Republic and beyond.

Expressionism was fueled by the stale governmental situation that paralyzed late $19^{\text {th }}$ century Europe. Expressionism became a way of mocking officials and leaders of European countries. By the time the First World War began, political distaste ran wild throughout Europe. Expressionism became a catalyst for change in Germany—an outlet for angered youths to retaliate against a government that was sending them off to fight with no regard if they lived or died. Expressionism took bold colors and graphic scenes to show the inner Angst artists and writers felt about the war. After the war ended, Expressionism was used as a way to depict the horrors young artists faced as they were forced to fight in a war they did not believe in.

Expressionism lasted through the horrors of war and became the first movement of a new form of government, the Weimar Republic. Expressionism shaped the lifestyle, 
architecture, and films of the Weimar Republic. It flourished in the early years of the Republic and would be the dominant form of art until 1924. But an ever-expanding need to express social issues pushed authors and artists to explore new art forms and ideas. As early as 1922 Neue Sachlichkeit began to take form. Many Expressionists of the time cursed Expressionism and moved to this new style. Neue Sachlichkeit allowed the artists and writers to focus more on content rather than form in a work and make their works more political. Other styles that emerged from Expressionism include Futurism and PostExpressionism. Even though these styles dominated the artistic scenes, Expressionism as a form continued to play a role as well. Expressionism influenced to works of many of these artists throughout their careers.

Expressionism's formative years were in the early $20^{\text {th }}$ century and it reached its peak between 1912 to 1924. By 1924, new styles like Neue Sachlichkeit began to take over and pushed Expressionism from the foreground of literature to the background. Film on the other hand, continued to use Expressionism until the late 1920s as evident by Metropolis. Even though Expressionism fell to the wayside of popularity, its influences can be seen well into the mid-1940s. Even during the Nazi period it continued to play a role, despite the Nazis adamant opposition to Expressionism. However, prominent artists of the Nazi era such as Hanns Johst used it to add feeling and emphasis to their works. After this period many Nazi artist and those in exile continued to curse Expressionism, but its influences can be found in the works of artists such as Bertolt Brecht as late as 1945. It was a style they used in their formative years that followed them through their careers. 
It should be noted that many of the artists and writers that cursed the name Expressionismus and voided any thought that their later works could be construed as Expressionism continued to use expressionistic form. The content left their works, but the form in which they learned, Expressionism, lingered on and influenced many of their works to come. This is evident with writers such as Johst and Brecht. Even though Johst and Brecht went on in their careers to use different literary styles, the form and psychological ideas of Expressionism continued to play minor roles in their writing styles. It was not just Johst and Brecht who continued to draw from Expressionism. Many other artists and writers mentioned in this paper also drew from Expressionism. These artists wished to depart from the content that formed Expressionism, however, they never disbanded the form of Expressionism.

Expressionism focused on how one character sees the world, which was likewise common of Impressionism. At the same time, it removed the use of the real human form and forced the viewer to see the harsh colors and distorted the figure. Expressionism worked less on developing characters as a whole but instead focused on making their characters a stereotype of the group he or she was representing. From Wedekind's writings many authors used the style. Bertolt Brecht, Alfred Döblin, Georg Kaiser, and Hanns Johst. Many more artists were influenced by Wedekind's writings such as Fritz Bleyl, Ernst Ludwig Kirchner, Wassily Kandinsky, and Franz Marc. Many of these artists followed the style in their early years, but they later claimed that they were not Expressionist. They despised the movement and their former title as Expressionist. This hate began in the early 20s and lasted until the end of Expressionisms (Gay, 143). 
Formal elements of Expressionism in literature, visual arts, and film of outdate the periodization of the canon. When looking at the form of Expressionism, one must expand the canon to include more works that follow expressionistic form. When one expands the canon to allow these new works and art pieces in, one will learn much more about what Expressionism was, how it affected those authors and artists who used it, how it shaped the Weimar years and later Germany, and what to look for in a work or painting in order to understand if the work or painting is expressionistic. 


\section{Works Cited}

Benjamin, Walter. The Origin of German Tragic Drama. London: Verso, 1998. Print.

Benson, Timothy O., and Edward Dimendberg. Expressionist Utopias: Paradise, Metropolis, Architectural Fantasy. Berkeley: U of California, 2001. Print.

Best, Otto F. Expressionismus und Dadaismus. Stuttgart: Ph. Reclam, 1974. Print.

Best, Otto F. Theorie des Expressionismus. Stuttgart: Reclam, 1976. Print.

Bletter, Rosemarie Haag. "Expressionism and the New Objectivity." Art Journal 43.02 (1983): 108-20. Print.

Braun, E. "Expressionism as Fascist Aesthetic." Journal of Contemporary History 31.2 (1996): 273-92. Print.

Brecht, Bertolt, and Eric Bentley. Baal, A Man's a Man, and The Elephant Calf: Early Plays by Bertolt Brecht. New York: Grove, 1964. Print.

Brecht, Bertolt, and Eric Bentley. The Caucasian Chalk Circle. Minneapolis: U of Minnesota, 1999. Print.

Brecht, Bertolt. Frühe Stücke: Baal, Trommeln in der Nacht, Im Dickicht Städte. Frankfurt Am Main: Suhrkamp, 1973. Print.

Brecht, Bertolt. Der kaukasische Kreidekreis. Frankfurt Am Main: Suhrkamp, 1970. Print.

Clarke, Jay A. "Neo-Idealism, Expressionism, and the Writing of Art History." Art Institute of Chicago Museum Studies 28.1 (2002): 24-37. Print.

Denkler, Horst. Einakter und kleine Dramen des Expressionismus. Stuttgart: Reclam, 1968. Print. 
Döblin, Alfred. Berlin Alexanderplatz: Die Geschichte vom Franz Biberkopf. Münschen: Deutscher Taschenbuch Verlag, 1965. Print.

Friedel, Helmut, Rosel Gollek, Sonja Mehl, and Armin Zweite. Museum Lenbachhaus München. München: Magazinpresse, in Zusammenarbeit Mit Westermann's, 1978. Print.

Gay, Peter. Weimar Culture: The Outsider as Insider. New York: Harper \& Row, 1968. Print.

Gruber, Helmut. "The Political-Ethical Mission of German Expressionism."The German Quarterly 40.2 (1967): 186-203. Print.

Johst, Hanns. Literarische Heldenverehrung im Nationalsozialismus. Hanns Johsts Drama 'Schlageter' S.1.: Grin Verlag Gmbh, 2014. Print.

Jonge, Alex De. The Weimar Chronicle: Prelude to Hitler. New York: Paddington, 1978. Print.

Kaiser, Georg, and Dennis Kelly. From Morning to Midnight. London: Oberon, 2013. Print.

Kaiser, Georg. Von morgens bis mitternachts. Stuttgart: Philipp Redam Jun., 1979. Print. Kracauer, Siegfried. From Caligari to Hitler: A Psychological History of the German Film. Princeton, NJ: Princeton UP, 1947. Print.

Kuiper, Kathleen. The Britannica Guide to Theories and Ideas That Changed the Modern World. New York, NY: Britannica Educational Pub. in Association with Rosen Educational Services, 2010. Print.

Lehnert, Herbert. Geschichte der Deutschen Literatur: vom Jugendstil zum Expressionismus. Stuttgart: Reclam, 1978. Print. 
Meyer, Theo. Theorie Des Naturalismus. Stuttgart: Reclam, 1973. Print.

Nietzsche, Friedrich Wilhelm and Walter Kaufmann. The Portable Nietzsche. New York, NY: Penguin, 1978. Print.

Schmähling, Walter. Naturalismus. Stuttgart: P. Reclam, 1977. Print.

Thompson, Kristin, and David Bordwell. "Germany in the 1920s." Film History: An Introduction. 3rd ed. Boston: McGraw-Hill, 2009. 101-18. Print.

Wagener, Hans. Frank Wedekind: Frühlings Erwachen. Stuttgart: Philipp Reclam Jun, 1980. Print.

Wedekind, Frank, Elisabeth Pablé, Charlotte Ryland, and Edward Bond. Spring Awakening. London: Methuen Drama, 2012. Print.

Weisstein, Ulrich. "German Literary Expressionism: An Anatomy." The German Quarterly 54.3 (1981): 262-83. Print.

Wiese, Benne Von. Das Deutsche Drama: Vom Realismus bis zur Gegenwart: Interpretationen II. Dusseldolf: August Bagel, 1980. Print.

Willett, John, and John Willett. Art and Politics in the Weimar Period: The New Sobriety, 1917-1933. New York: Pantheon, 1978. Print.

Ziolkowski, Theodore. "Zarathustra's Reincarnations: Literary Responses to Nietzsche's Work." The Modern Language Review 107.1 (2012): 211-29. Print.

Zweite, Armin, and Annegret Hoberg. The Blue Rider in the Lenbachhaus, Munich: Masterpieces by Franz Marc, Vassily Kandinsky, Gabriele Münter, Alexei Jawlensky, August Macke, Paul Klee. Munich: Prestel, 1989. Print. 